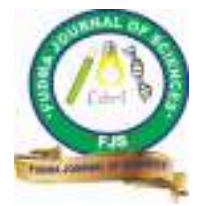

FUDMA Journal of Sciences (FJS)

ISSN online: $2616-1370$

ISSN print: 2645 - 2944

Vol. 4 No. 3, September, 2020, pp 523-530

DOI: https://doi.org/10.33003/fjs-2020-0403-285

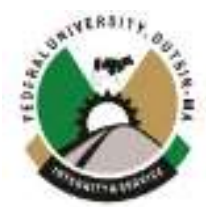

\title{
QUALITATIVE PHYTOCHEMICAL EVALUATION AND IN VITRO INHIBITION OF Mycobacterium tuberculosis USING METHANOLIC EXTRACTS OF Calotropis procera and Garcinia kola
}

\author{
${ }^{* 1}$ Aminu A, ${ }^{2}$ Aliyu B. S., ${ }^{3}$ Abdulkadir S., ${ }^{4}$ Umar R. B. and ${ }^{5}$ Maigari A. K. \\ ${ }^{1}$ Department of Trypanosomiasis Research Nigerian Institute for Trypanosomiasis Research, Kano State Liaison Office France \\ Road, Kano State, Nigeria. \\ ${ }^{2}$ Department of Biological Sciences, Bayero University, PMB 3011, Kano, Kano State. Nigeria \\ ${ }^{3}$ Department of Plant Science Bayero University, Kano State, Nigeria. \\ ${ }^{4}$ Department of Biology Sa'adatu Rimi College of Education Kumbotso, Kano State, Nigeria \\ ${ }^{5}$ Department of Integrated Sciences Sa'adatu Rimi College of Education Kumbotso, Kano State, Nigeria \\ *Corresponding Author's Email: halifaone@gmail.com, +2348032076327
}

\begin{abstract}
Extracts of herbal plant samples which include leaves and seeds of Calotropis procera and Garcinia kola respectively were investigated for phytochemical content and tested against clinical isolates of Mycobacterium tuberculosis (in-vitro). 95\% methanolic extract of the plant samples were obtained by percolation. The anti-mycobacterial activity was determined using disc diffusion method; Anova single factor was statistically used for the analysis. The crude methanol extract of Calotropis procera leaf and Garcinia kola seed reveal a final weight of $8.1 \mathrm{~g}$ and $19.1 \mathrm{~g}$, tannins and flavonoids were the phytochemical compounds found to be present in all the plant samples. Rifampicin antibiotic was used as control and the antimycobacterial activity for the plant sample shows that $C$. procera has the highest zone of inhibition followed by G. kola, the minimum inhibitory concentration ranging from 500-2000ug/ml. The M.I.C of $95 \%$ methanol extract in the order mention above are $500-2000 \mathrm{ug} / \mathrm{ml}$ and $1000-2000 \mathrm{ug} / \mathrm{ml}$. The result support the local use of these plants in the treatment of tuberculosis and it is suggested that these plants may have therapeutic value in the treatment of Tuberculosis. However, further investigations should be focused toward isolating chemical constituent that are responsible for pharmacological activities and identifying the compound eliciting the activities observed in the plant samples.
\end{abstract}

Keywords: Phytochemical, Methanol extracts, Calotropis procera, Garcinia kola, Mycobacterium tuberculosis.

\section{INTRODUCTION}

Tuberculosis (TB) is a chronic bacterial infection caused byMycobacterium tuberculosis. It is easily transmitted from one person to another through the air by droplet nuclei (Moulding, 1988). Tuberculosis remains a leading cause of death in the world from a single infectious agent.It is estimated that onethird of the world's population is infected with the tubercles bacillus and about $80 \%$ of individuals diagnosed with the disease every year live in the 22 most populous countries such as China, India and Pakistan (Dye, 2006). Medicinal plants have enjoyed use in virtually all cultures as sources of medicines (Plotkin, 1991). The history of the use of medicinal plants for their therapeutic purposes probably dates back to the origin of man. Fossil records date human use of plants as medicines to at least the middle Paleolithic age, some 60,000 years ago (Solecki, 1977). Ancient texts of India and China contain exhaustive depictions of the use of a variety of plantderived medications (Ahmed et al., 2006).

In Africa, Asia and Latin America, traditional medicine and medicinal plants have continued to play a very important role in their health care delivery systems. According to the World Health Organization (WHO 2003a), it is estimated that about $80 \%$ of the population in these developing countries rely on traditional medicine for their primary health care needs. There has also been an increase on the reliance of the use of medicinal plants by the population in the industrialized societies, as herbal remedies have become more popular in the treatment of minor ailments and also on account of the increasing costs of personal health maintenance (Horeau and Dasilva, 1999). In 2001, it was estimated that approximately $25 \%$ of prescription drugs originated from plants, 121 active compounds were then in use (Houghton, 2001; Rates, 2001).

However, the difficulty in the use of medicinal plants is that they are used without any standardization. This makes it difficult to document and institute a system of verification or assessment of the efficacy of the treatment. Thus, the local herbal medicine practitioner is quick to profess the efficacy of these remedies but stops short of providing a sound scientific basis and explanation for the remedy and more often than not thrives on the long, continuous and sometimes uneventful use of the remedy for treatment. Plants may contain constituents that can be used to treat diseases such as infections, inflammatory conditions and cardiovascular diseases, but the scientific information on most of these medicinal plants in use are lacking. Therefore, as part of the efforts to promote the use of medicinal plants either as an alternative or an adjunct to conventional medicine, it is necessary for scientists to carry out investigations into herbal medicines. This will help bridge the gap between conventional and herbal medicines. For a long 
time, medicinal plants and herbs were used intensively in folkloric medicine for treatment of various diseases. Among the plant species that show relevant significant importance include Calotropis procera and Garcinia kola. On the part of Calotropis procera, the leaf is traditionally considered for the treatment of tuberclosis and it is a flowering plant in the dogbane family, Apocynaceae, that is native to North Africa, Western Africa, South Asia, and China. The green globes are hollow but the flesh contains a toxic milky sap that is extremely bitter and turns into a gluey coating resistant to soap. Common names for the plant include Sodom apple, King's crown, rubber bush, or rubber tree. The name apple of Sodom is derived from Hebrew; the milky sap contains a complex mixture of chemicals, some of which are steroidal heart poisons known as "cardiac aglycones". These belong to the same chemical family as similar chemicals found in foxgloves (Digitalis purpurea).

Garcinia kola Bitter cola is another plant species used in the treatment of tuberculosis, the plant is essentially found in some parts of Nigeria. It belongs to the family "Guittiferrae". Among the Yorubas, it is called 'Orogbo', the Igbos calls it 'Agbilu', 'Adi' or 'Aki ilu' while to Hausas, this very popular nut is known as 'Namijin Goro.' It is a wonderful agricultural product with a wide range of applications in natural and orthodox medicine. Bitter kola is potent, with antibiotic properties, which could be effective in the treatment of many ailments and infections. Bitter kola has lots of health benefits, like the treatment of cough, sneezing, cold, diarrhea, tuberculosis, bacterial infection and fever."It improves lung function by expanding the alveolar ducts and sac in the lungs thereby improving and strengthening the fibers in the lung tissue" (De Caluwé et al., 2009).

\section{Study Area}

The study was conducted at Infectious Diseases Hospital (I.D.H), located at France road, Kano, state, Northern Nigeria. The state is within the savannah zones of the country, latitude $11^{\circ} 30^{\prime \prime} \mathrm{N}$ and longitude $8^{\circ} 30^{\prime \prime} \mathrm{E}$. It has an elevation of about 525 meters above the mean sea level.

Collection, Identification and Preparation of the plant materials.

The plants used in this study were selected from the list of plants used by local herbalist in the preparation of various medicaments and their history in the folkloric medicine, used for curing tuberculosis. Two plants i.e. seed of Garcinia kola (Bitter kola) and leaves of Calotropis procera (Sodom apple) were collected. They were properly identified at the Department of Plant Biology, Bayero University Kano with the following herbarium accession number

A. Calotropis procera (Sodom apple) BUKHAN 0132

B. Garcinia kola (Bitter kola) BUKHAN 0433)

C.

\section{Calotropis procera}

The leaf of plants Calotropis procera (Sodom apple) was collected from the old campus of Bayero University kano which is located between latitude $13^{\circ} 2^{1} \mathrm{~N}, 42^{\circ} \mathrm{E}$ in Gwale local government area of Kano state Northern Nigeria. The leaf of the growing plant collected, was thoroughly washed under running tap water and rinsed with distilled water and finally shade dried. The dried leaves were crushed into powder form using motor and pestle as described by Fatope et al.(1999).
Powdered samples were then stored into air- tight container until used.

\section{Garcinia kola}

The Garcinia kola was bought from the popular Mariri 'Yangoro Market of Kumbotso local government area, of Kano state. It was peeled and washed using running tap water and then rinsed with distilled water, later the seeds were crushed using mortar and pestle, spread under shade till it was dried and then kept in a container until used.

\section{Extraction and Preparation of the Plant Material}

Two hundred grams each of the powdered plant sample was extracted exhaustively with $95 \%$ methanol. The percolation processes was carried out on each of the fine powdered plant sample. The processed plant material was placed in closed vessels, followed by addition of $95 \%$ methanol and then later allowed to stand for fourteen days with regular shaking occasionally under room temperature. The extracts were then filtered through Whatman filter paper, No.3. Solid residue was pressed to recover much solution, liquid strained off. The percolation process was repeated three times, the second and third residue were allowed to stand until it is evaporated before adding to the first residue, concentrated extract of $C$. Procera yielded (8.1g) and G. kola $(19.1 \mathrm{~g})$ and was referred to as Crude Methanol Extract (CME). Filtrates were labelled and stored respectively until used.

\section{Preliminary Phytochemical Screening}

The screening methods were carried out using the procedure described by Harbone (1984), Sofowora (1986), Mukhtar and Okafor (2002). The following active constituents were tested for: - alkaloids, tannins, flavonoids, cyanogenic glycosides, anthraquinone, saponins, anthrocyanosides (anthrocyanin pigment) and reducing sugar compounds.

\section{Test for Terpenes:}

\section{Salwoski test:}

$0.3 \mathrm{~g}$ of the extract was dissolved in $1 \mathrm{ml}$ chloroform followed by addition of $1 \mathrm{ml}$ of concentrated $\mathrm{H}_{2} \mathrm{SO}_{4}$ down the side of the test tube to form two phases. Formation of red or yellow coloration indicated the presence of sterols (Silva et. al., 1998).

\section{Test for flavonoids:}

Sodium hydroxide test:

$0.3 \mathrm{~g}$ of the extract was dissolved in water and filtered. To this, $2 \mathrm{ml}$ of $10 \%$ aqueous sodium hydroxide was added to produce a yellow coloration. A change of color from yellow to colorless on addition of dilute hydrochloric acid was an indication of the presence of flavonoids (Trease and Evans, 2002).

\section{Test for Alkaloids:}

$0.5 \mathrm{~g}$ of the extract was stirred with $5 \mathrm{ml}$ of $1 \%$ aqueous $\mathrm{HCl}$ on water bath and then filtered, $1 \mathrm{ml}$ each of the filtrate was taken in two test tubes. To the first portion few drops of Dragendorff's reagent were added to observe the presence of orange-red precipitate while to the second portion $1 \mathrm{ml}$ of Mayer's reagent was added. Formation of a blue colored precipitation indicated the presences of alkaloids (Sofowora, 1993).

\section{Test for Tannins:}


About $0.5 \mathrm{~g}$ of the extract was stirred with $10 \mathrm{ml}$ of distilled water and then filtered. Few drops of $1 \%$ ferric chloride solution were added to $2 \mathrm{ml}$ of the filtrate, formation of a blueblack, green or blue-green precipitate indicated the presence of tannins (Trease and Evans, 2002).

\section{Test for Saponins:}

About $0.5 \mathrm{~g}$ of the extract was shaken with water in a test tube. Frothing which persist for 15 minutes indicated the presence of saponins (Silva et al., 1998).

\section{Test for Anthraquinones}

$0.5 \mathrm{~g}$ of extract was shaken with $10 \mathrm{ml}$ of benzene, the conten was filtered and $5 \mathrm{ml}$ of $10 \%$ ammonia solution was added to the filtrate the mixture was shaken. Presence of a pink, red or violet color in the ammoniacal layer (lower phase) indicated the presence of free anthraquinones (Trease and Evans, 2002).

\section{Test for glycoside}

\section{Keller-killiani Test}

The extract was reduced to dryness after which $5 \mathrm{mg}$ was dissolved in $2 \mathrm{ml}$ chloroform. Tetraoxosulphate (VI) acid was added to form a layer and the purple color at the inter-phase indicated the presence of glycosides (Trease and Evans, 2002).

\section{Test for carbohydrates}

Fehling's Test

Fehling A and Fehling B reagents were mixed together and few drops of extracts were added and boiled. A brick red colored precipitate of cuprous oxide forms, confirmed the presence of carbohydrates (Trease and Evans, 2002).

\section{Test for reducing sugars}

One $\mathrm{ml}$ each of Fehling's solutions I and II was added to $2 \mathrm{ml}$ of the aqueous solution of the extract. The mixture was heated in a boiling water bath for about $2-5 \mathrm{~min}$. The production of a brick red precipitate indicated the presence of reducing sugars(Silva et al., 1998).

\section{Test for steroids}

Salkowski method was used to test for steroids. About $0.5 \mathrm{~g}$ of the extract was dissolved in $3 \mathrm{ml}$ of $\mathrm{CHCl}_{3}$ and filtered. To the filtrate concentrated $\mathrm{H}_{2} \mathrm{SO}_{4}$ was added to form a lower layer. A reddish brown color was taken as positive for steroid ring(Silva et al., 1998).

\section{Test for Amino Acid (Ninhydrin test)}

Two drops of freshly prepared $0.2 \%$ ninhydrin reagent was added to $0.3 \mathrm{~g}$ of the extract and heated, Development of blue color indicated the presence of Amino acids(Trease and Evans, 2002).

\section{Test for proteins (Biuret test)}

$0.3 \mathrm{~g}$ of the extract was added to $1 \mathrm{ml}$ of $40 \%$ sodium hydroxide and 2 drops of $1 \%$ copper sulfate solutions were added. A violet color indicated the presence of proteins(Trease and Evans, 2002)

\section{Test for resins}

Two $(2 \mathrm{~g})$ of the methanolic extract was dissolved in $10 \mathrm{ml}$ of acetic anhydride. A drop of concentrated sulphuric acid was added. Appearance of purple color, which rapidly changed to violet, was indicative of the presence of resins (Trease and Evans, 2002).

\section{Test Organism}

Clinical isolate of mycobacterium tuberculosis were used in the study and it was collected from infectious diseases hospital (I.D.H) Kano.

\section{Inoculums preparation}

A sterilized wire loop was used to scrape the colony of Mycobacterium and it was dipped into $5 \mathrm{ml}$ normal saline solution and gently shaken. The turbidity of the actively growing bacterial suspension was adjusted to match the turbidity standard of 0.5 Macfarland unit, it was prepared by mixing $0.5 \mathrm{ml}$ of $1.75(\mathrm{w} / \mathrm{v})$ barium chloride dehydrate with $99.5 \mathrm{ml}$ of $1 \%(\mathrm{v} / \mathrm{v})$ sulphuric acid. The grown suspension was used for further testing.

\section{Preparation of stock solution}

The stock solution of plant extract was prepared in a screwed capped bijou bottle different concentration ranging from $(250,500,1000 \mathrm{and} 2000 \mu \mathrm{g})$ of the extract was dissolved in $5 \mathrm{ml}$ Dimethly sulphoxide (D.M.S.O) and the solution was kept at room temperature until used.

\section{Preparation of Culture Media}

About $6.2 \mathrm{~g}$ of Lowenstein-Jensen (LJ) powdered medium was measured and poured into a conical flask containing $100 \mathrm{ml}$ of sterile distilled water. It was then shaken until the media dissolved evenly into the solution. The conical flask was then covered with foil paper to avoid impurities from air. Thereafter, it was taken into an autoclave for between $45-50 \mathrm{~min} .2 \mathrm{ml}$ of glycerol was added into the conical flask containing the L.J medium, aseptically a fresh egg was smashed into a beaker and stirred gently until it was evenly mixed. The egg mixture was poured into the conical flask containing the media, while continuously shaking until mixed evenly. The L.J solution was then poured into Petri-dish and allowed to cool and hardened. Later the Petri-dishes were sealed up with tape to prevent air passage and kept at room temperature until used, as it was described by manufacturer.

\section{Preparation of Sensitivity Discs}

Sterilized paper disc of No 1 Whatmann filter paper was punched using puncher to an approximately $6.0 \mathrm{~mm}$ in diameter and were placed in a screwed capped bijou bottle and sterilized in dry heat oven at $140^{\circ} \mathrm{C}$ for 1 hour and the discs were allowed to cool $500,1000,2000,5000$ and $10,000 \mu \mathrm{g} / \mathrm{ml}$ of each plant extract concentration was dissolved in Dimethly sulphoxide (D.M.S.O) solution. The sterilized paper discs were soaked in each concentration of plant extract sample respectively and allowed to stand until it soaked all the solution. They were kept at room temperature until used. Standard Rifampicine antibiotic disc was used as control.

\section{Bioassay Procedure}

The antimycobacterial activities of the extract were determined by the Kirby-Bauer (1966) agar diffusion method according to NCCLS standard (2000). Lowenstein Johnson medium were used for the antimycobacterial test under septic condition. $15 \mathrm{ml}$ of the L.J medium were dispensed into pre-sterilized Petri-dish. 
A sterile wire loop was dipped into the prepared inoculum of Mycobacterium tuberculosis isolate and then it was gently streaked on the Petri-dish turning the plate to an angle $360^{\circ}$ until the entire surface of the media was covered. Using sterile forceps aseptically the sterile extract discs were placed on the surface of each inoculated media and they were pressed down gently to ensure contact with the agar surface. The discs were spaced about $20 \mathrm{~mm}$ to avoid overlapping ring of the zone of inhibitions and the control disc of rifampicine was placed at the center of the Petri-dish. It was then covered and incubated. Readings was taken on the $7^{\text {th }}$ day after inoculation and subsequently once a week for five weeks.

\section{Minimum Inhibitory Concentration (MIC)}

Minimum Inhibitory Concentration (MIC) is the lowest concentration of the plant extract that inhibits the visible growth of Mycobacterium. This was done using agar well diffusion method as described by Kirby-bauer (1966) and demonstrated by Arzai (2002).From the prepared inoculum wire loop was used to streak on the surface of the Lowenstein Johnson medium. Using a sterilized cock borer a hole of about $4 \mathrm{~mm}$ was punched into the media leaving a space in between each hole. About $0.5 \mathrm{ml}$ of each prepared extract concentration was pipette and poured into respective hole. Readings were observed on each Petri-dish and recorded.

\section{RESULTS}

Phytochemical studies

Phytochemical studies were conducted on methanolic extract of the two plant species. Result indicated that the extract had different characteristics in terms of color, odor and texture. $G$. kola yielded more in weight (19.1g).

Table 1: Physical characteristics of Crude Methanol Extracts (C.M.E) of the plant samples

\begin{tabular}{lcccccc}
\hline Plant sample Plant part & Initial weight (g) Final weight $\mathbf{( g )}$ Color & Odor & \multicolumn{2}{c}{ Texture } & \\
\hline C. procera & Leaf & 200 & 8.1 & \multicolumn{2}{c}{ Green Repulsive } & Oily \\
G. kola & Seeds & 200 & 19.1 & Black Repulsive Oily & Re
\end{tabular}

From the phytochemical characteristics of the crude methanol extract of the two plants, tannins and flavanoids were found to be present among in both plants, while resins were absent. Furthermore there was variation in the occurrence of the phytochemicals among the plant as $G$. kola had saponins while $C$. procera had glycosides and steroids.

Table 2:Phytochemical characteristics of the plant extracts

\begin{tabular}{|c|c|c|}
\hline & & \\
\hline Phytochemical & C. procera & G. kola \\
\hline Carbohydrates & + & _- \\
\hline Tanins & + & + \\
\hline Terpenoides & - & - \\
\hline Flavanoids & + & + \\
\hline Saponins & _- & + \\
\hline Alkaloids & - & + \\
\hline Glycosides & + & - \\
\hline Anthroquinone & - & + \\
\hline Proteins and amino acids & + & - \\
\hline Steroids & + & _ \\
\hline Reducing sugar & - & + \\
\hline Resin & - & - \\
\hline
\end{tabular}

Key (+) Detected (-) Not Detected

From the results in table 3 below, it could be seen that Calotropis procera, Garcinia kola, and Rifampicin had a mean diameter (zone of inhibition) of $11.38 \mathrm{~mm}, 6.2 \mathrm{~mm}$, and $17.8 \mathrm{~mm}$ respectively.

Table 3. Diameter of zone of inhibition (mean \pm std) of the plant extracts 


\begin{tabular}{lll}
\hline Treatment & N & (Mean Diameter of Inhibition Zone) \\
\hline Calotropis procera & 25 & $11.3 \pm 4.9506969$ \\
Garcinia kola & 25 & $6.2 \pm 3.8367738$ \\
Rifampicin & 25 & $17.8 \pm 9.5410202$ \\
Total & 75 & $10.2 \pm 7.7620076$ \\
\hline
\end{tabular}

N----- Total Number of samples

From the results presented in the table 4 below it could be seen that Garcinia kola fell within a subset 1 with a zone inhibition $6.20 \mathrm{~mm}$. Calotropis procera fell under subset 2 with a zone of inhibition having a diameter of $11.40 \mathrm{~mm}$ and the Rifampicin which is the control has a diameter of $17.80 \mathrm{~mm}$ around the zone of inhibition. The study further revealed that Garcinia kola had lower effect on the Mycobacterium tuberculosis compared to Calotropis procera. Both plant extracts (Garcinia kola and Calotropis procera) were not as effective as Rifampicin.

Table 4:Scheffle Multiple Comparison Test of the plant extract on inhibition of Mycobacterium tuberculosis growth.

\begin{tabular}{|c|c|c|c|}
\hline $\begin{array}{l}\text { Zone of Inhibition (mm) } \\
\text { (Treatment) }\end{array}$ & $\mathbf{N}$ & Subset for alpha $=0.05$ & \\
\hline & & $1 \quad 2$ & 3 \\
\hline Garcinia kola & 25 & 6.20 & \\
\hline Calotropis procera & 25 & 11.40 & \\
\hline Rifampicin & 25 & & 17.80 \\
\hline
\end{tabular}

Means for groups in homogeneous subsets are displayed

From the results in the table 5 below, the Calotropis procera concentrations at 500, 1000, 2000, $5000 \mathrm{and} 10000 \mu \mathrm{g} / \mathrm{ml} \mathrm{had} \mathrm{mean}$ diameters of $7.06 \mathrm{~mm}, 8.92 \mathrm{~mm}, 11.96 \mathrm{~mm}, 11.96 \mathrm{~mm}$ and $16.98 \mathrm{~mm}$ respectively.

Table 5:Effect of Calotropis procera leaf extract on inhibition of Mycobacterium tuberculosis growth.

\begin{tabular}{lll}
\hline Concentration & N & Mean \pm std. \\
\hline $500 \mu \mathrm{g} / \mathrm{ml}$ & 5 & $7.06 \pm 2.01817$ \\
$1000 \mu \mathrm{g} / \mathrm{ml}$ & 5 & $8.92 \pm 4.21746$ \\
$2000 \mu \mathrm{g} / \mathrm{ml}$ & 5 & $11.96 \pm 3.78259$ \\
$5000 \mu \mathrm{g} / \mathrm{ml}$ & 5 & $11.96 \pm 3.78259$ \\
$10000 \mu \mathrm{g} / \mathrm{ml}$ & 5 & $16.98 \pm 5.06429$ \\
Total & 25 & $11.38 \pm 4.9507$ \\
\hline
\end{tabular}

From the results presented in the table 6 below it could be seen that the $500 \mu \mathrm{g} / \mathrm{ml}, 1000 \mu \mathrm{g} / \mathrm{ml}, 2000 \mu \mathrm{g} / \mathrm{ml}, 5000 \mu \mathrm{g} / \mathrm{ml} \mathrm{had}$ fallen within a subset group 1 having a diameter (zone of inhibition) of $7.06 \mathrm{~mm}, 8.92 \mathrm{~mm}, 11.96 \mathrm{~mm}$ and $11.96 \mathrm{~mm}$ respectively and they had similar effect on the Mycobacterium tuberculosis while concentration level of $10000 \mu \mathrm{g} / \mathrm{ml}$ with a diameter of $16.98 \mathrm{~mm}$ had fallen under the subset group 2. The analysis therefore reveals that the Calotropis procera concentration level of $10000 \mu \mathrm{g} / \mathrm{ml}$ is the most effective and therefore the analysis accepted the alternative hypothesis and rejects the null hypothesis.

Table6: Multiple comparison test for the Calotropis procera concentration levels on inhibition of Mycobacterium tuberculosis growth.

\begin{tabular}{|c|c|c|}
\hline Concentration of Calotropis procera & $\mathbf{N}$ & Subset for alpha $=0.05$ \\
\hline \multirow[b]{2}{*}{$500 \mu \mathrm{g} / \mathrm{ml}$} & & 2 \\
\hline & 5 & 7.06 \\
\hline $1000 \mu \mathrm{g} / \mathrm{ml}$ & 5 & 8.92 \\
\hline $2000 \mu \mathrm{g} / \mathrm{ml}$ & 5 & 11.96 \\
\hline $5000 \mu \mathrm{g} / \mathrm{ml}$ & 5 & 11.96 \\
\hline \multicolumn{3}{|l|}{$10000 \mu \mathrm{g} / \mathrm{ml}$} \\
\hline & 5 & 16.98 \\
\hline
\end{tabular}

Means for groups in homogeneous subsets are displayed

The result indicated that $C$. procera leaf extract was effective across the concentration used but was not effective at $250 \mu \mathrm{g} / \mathrm{ml}$, 
and G. kola seed extract showed inhibition at $2000 \mathrm{ug} / \mathrm{ml}$ and $1000 \mathrm{ug} / \mathrm{ml}$ but growth was not inhibited at $500 \mathrm{ug} / \mathrm{ml}$ and $250 \mathrm{ug} / \mathrm{ml}$.

Table7: Minimum inhibitory concentration of C.M.E of plant sample on inhibition of Mycobacterium tuberculosis growth.

\begin{tabular}{llcccc}
\hline & \multicolumn{5}{c}{ Extract concentration $(\boldsymbol{\mu g} / \mathbf{m l})$} \\
\hline Plant sample & $\mathbf{2 0 0 0}$ & $\mathbf{1 0 0 0}$ & & $\mathbf{5 0 0}$ & $\mathbf{2 5 0}$ \\
\hline C. procera & + & + & + & - \\
G. kola & + & + & & - & - \\
\hline
\end{tabular}

Key:(+) Growth inhibited, (-) Growth not inhibited

\section{DISCUSSION}

Phytochemical analysis is very useful in the evaluation of bioactive and biochemical components of seeds and other parts of plants. The results of the preliminary phytochemical screening carried out on the crude methanolic extracts of Calotropis procera and Garcinia kola revealed the presence of tannins and flavonoids in both plant samples. This agrees with the work of (Musa et al., 2000) which also found the same phytochemical in C. procera leaf. Carbohydrate, proteins and amino acids occurred only in Calotropis procera while alkaloids, anthroquinones and reducing sugar were only present in G. kola. (Kawo et al., 2009) also reported similar phytochemicals during extraction of $C$. procera leaf and latex The phytochemical constituents may be associated with the antimicrobial activities of the plant (should be the other way round. In any case, you have not stated your own result before discussing it). Tannins and flavonoids have been reported to possess antimicrobial activities (Cowan, 1999). Thus the antimicobactarial activity of tannins may be related to their ability to inactivate microbial adhesion of enzymes (Cowan, 1999). Tannins have been reported to inhibit growth of microorganisms by precipitating microbial protein and making nutritional proteins unavailable to them (Ogunleye and Ibitoye, 1986). The result obtained in the experiments agreed with an earlier report of Aliyu (2006) who recorded similar results for the extract of Garcinia kola. He further reported that the invaluable pharmacological potential of Garcinia kola such as antioxidant, antibacterial, antiviral, antifungal and antiinflammatory properties may be attributed to the presence of these bioactive compounds. The presence of these components in this species is an indication that it may have some medicinal potential. This is due to the fact that each of the components identified has one therapeutic usage or another. For instance plants rich in saponins have immune boosting and anti inflammatory properties (Kenner and Requena, 1996) Similarly, tannins have been reported to have antibacterial potential due to their basic character that allows them to react with proteins to form stable water soluble compounds thereby killing bacteria by directly damaging its cell membrane (Elmarie and Johan, 2001). The antibacterial activities of alkaloids and flavonoids have been reported by a number of authors (Hassan et al., 2005; Aliero et al., 2008; Yesmin et al., 2008). Elsewhere in Democratic Republic of Congo similar observations have been made on plants employed for traditional medicines, which were known to contain the above mentioned bioactive components (Otshudi et al., 2000).

The ant tubercular activity of methanolic plant extracts of $(C$. procera, G. kola,) and rifampicine (control) tested against the isolate (M. tuberculosis) has a mean diameter (zone of inhibition) of $11.38 \mathrm{~mm}, 6.2 \mathrm{~mm}$, and $17.8 \mathrm{~mm}$ respectively, as it was presented in table 3 , however, it could be seen that between the two plant samples, $C$. procera had a higher mean value (zone of inhibition).This indicated that the plants have different activities on Mycobacterium tuberculosis isolate

The plant extract and the control were grouped into 3 category or sub set. G. kola fell under $1^{\text {st }}$ category or subset with zone of inhibition $(6.28 \mathrm{~mm})$ due to the closeness of their inhibition zone while $C$. procera was in the $2^{\text {nd }}$ category or subset with $11.40 \mathrm{~mm}$ zone of inhibition. That was much higher than the other plant extract. Rifampicin was the control and has a diameter of $17.5 \mathrm{~mm}$ zone of inhibition. This was greater than the $C$. procera and it was the $3^{\text {rd }}$ category or subset. The multiple comparison tables shows that G. kola had the same effect but were least in terms of effect on Mycobacterium tuberculosis isolate compared to C. procera.

From the analysis done above it was found out that $C$. procera is having the highest degree of influence among the plant extract. It is of paramount importance to find out which of the concentrations will be most effective in the treatment of the Mycobacterium tuberculosis isolate which led us to further analysis of variance in respect concentration which ranges from $(500,1000,2000,5000,10,000 \mu \mathrm{g} / \mathrm{ml})$.

From the descriptive statistics on the concentration of $C$. procera (table 6) it will be seen that 500, 1000, 2000, 5000 and $10,000 \mu \mathrm{g} / \mathrm{ml}$ had mean diameter (zone of inhibition) of $7.06 \mathrm{~mm} \quad 8.92 \mathrm{~mm}, 11.96 \mathrm{~mm}, 11.96 \mathrm{~mm}$ and $16.98 \mathrm{~mm}$ respectively. Analysis of variance revealed a significant variation among the concentration levels at $1 \%$ probability. This led to accept the alternate hypothesis that says at least one of the concentrations had more significant effect in the treatment of Mycobacterium tuberculosis isolate than the other, and this was found to be $10,000 \mu \mathrm{g} / \mathrm{ml}$ with the highest diameter (zone of inhibition) of $16.98 \mathrm{~mm}$. The result agrees with the work of Johnson et al. (2000) also reported that plant used to treat T. B. in Mbarara district is G. kola which contains some of the chemical constituent. Moreover Gill (1992) also stated that $C$. procera has some ameliorative effect on nasophaningeal and pulmonary diseases.

For the minimum inhibitory concentration the result indicated that $C$. procera leaf extract was effective across the concentration used but was not effective at $250 \mu \mathrm{g} / \mathrm{ml}$, G. kola seed extract showed inhibition at $2000 \mathrm{ug} / \mathrm{ml}$ and $1000 \mathrm{ug} / \mathrm{ml}$ but growth was not inhibited at $500 \mathrm{ug} / \mathrm{ml}$ and $250 \mathrm{ug} / \mathrm{ml}$.

\section{CONCLUSION}

Its shows that the phytochemical analysis of the plant samples contain tannins, flavonoids, proteins and amino acids to mention but few and the crude methanolic extract of the two plant samples possess some antimicrobial activities with $C$. procera having the highest degree of activity due to the higher 
zone of inhibition followed by $G$. kola with moderate activity among the plant extract. However all of them were not as effective as the control (Rifampicine). This provides the basis for the use of the plant in traditional medicine. However to evaluate the potential effectiveness in human beings, further studies are needed.

\section{REFERENCES}

Ahmed, M., Amin, S., Islam, M., Takahashi, M., Okuyama, E., and Hossain, C.F. (2006) Analgesic Principle from Abutilon indicum. Pharmazie 55:314

Aliero, A.A., B.L. Aliero, and U. Buhari (2008). Preliminary Phytochemical and Antibacterial screening of Scadoxus maltiflorus, International Journal of Pure and Applied Sciences. 2(4); 13- 17

Arzai, H.A. (2002). Preparation of Wet disk for Sensitivity Testing (Undergraduate Lecture notes) Unpublished, Bayero University, Kano.

Ayele W.Y., Svastova P., Roubal P., Bartos M., Pavlik I. (2008): Mycobacterium avium Sub-species para-tuberculosis cultured from locally and commercially pasteurized cow's milk in the Czech Republic. Applied and Environmental Microbiolog Journaly, 71, 1210-1214.

Aliyu, S.B. (2006). Common Ethnomedicinal plants of the semi arid regions of West Africa their description and phytochemicals, Triumph Publishing Company Limited Kano, Nigeria. Pp 193-196

Cowan, M.M. (1999). Plants Products as Antimicrobial agents. Clinical Microbialogy Review 12: 564-582

De Caluwé, E., Halamová, K., and Van Damme, P., (2009). Baobab (Adansoniadigitata L.): Areview of traditional uses, phytochemistry and pharmacology. In: Rodolfo, H., Simon, J.E., Ho, C.-T. (Eds.), African natural plant products: new discoveries and challenges in chemistry and quality. Oxford University Press, USA, pp. 51-84.

Dye,C.,(2006).Global epidemiologyof tuberculosis Lancet 367,938-940.

Elmarie, V.W. and Jonah, C.P. (2001). Purification and identification of active antibacterial component in Carpobrotus edulis. Journal of Ethnopharmacology. 76: 87-91

Fatope M. O Ibrahim H., and Takeda Y. (1999) screening of higher plants reported as pesticides using brine shrimps assay. International Journal of pharmacognosy volume3 number1 Pp 250-260.

Hassan, S. W., Umar, R. A., Ebbo,A. A., and Matazu, I.K. (2005). Phytochemical, antibacterial

and toxicity studies of Parkinsonia aculeate L. (Fabaceae), Nigerian Journal of Biochemistry and Molecular Biology. 20(2): 89-97

Harbone, J. B. (1984). Phytochemical Methods, In: A guide to modern techniques of plant analysis. Fakenhan Press, Britain
$162-167$

Hoareau, L. and DaSilva, E. J. (1999). Medicinal plants: a reemerging health aid. ElectronicJournal of Biotechnology, 2, 5670.

Houghton, P. J. (2001). Old yet new pharmaceuticals from plants,Journal of Chemical Education. 78(2), 175-184.

Johnson E, Long NH, Diwan VK, and Winkvist A, (2000). Gender and tuberculosis control: perspectives on health seeking behavior among men and women in Vietnam. Health Policy 52:33-51.

Kawo, A. H., Mustapha, A., Abdullahi, B. A., Rogo, L. D., Gaiya, Z. A. and Kumurya, A. S. (2009). Phytochemical Properties and Antibacterial Activities of the leaf and latex extracts of Calotropis procera. Bayero Journal of Pure and Applied Sciences, 2(1):34-40

Kenner D and Requena Y (1996) Botanical medicine, a European professional perspectives paradigm publication Brookline Massachusetts p7-12

Kirby - Bauer (1966). Antimicrobial Sensitivity Testing by Agar Diffusion Meth. African Journal of Clinical Pathology, 44: 493.

Moulding,T.,(1988).Pathogenesis,PathophysiologyandImmunol ogy.In:Schloss-berg, D.(Ed.), Tuberculosis, 2nd edition. Springer-Verlag, NewYork, pp.13-22.

Musa, K.Y., A. Ahmed, H. Ibrahim, G. Arowosaiye and O.S. Olonitola (2000): Phytochemicaland antimicrobial studies of Acalypha racemosa . Nigerian Journal of Natural Products and Medicine 4 :67-69.

Mukhtar, M.D. and Okafor A.C. (2002). Bioactive Evaluation of Ethanol Extracts of Leaf and Stem - Bark of Guiera Senegalensis. Nigeria Journal of Research and Production 1 (1) Pp. $114-121$

Ogunleye B and Ibitoye E, (1986) Medicinal plants in tropical West Africa. Cambridge University Press, London

Otshudi, A. L, Foriers, A.,Vercryise, A., VanZeebrockect, A. and Lawwers, S. (2000). In vitro antibacterial activities of six medicinal plants traditionally used for the treatment of dysentery and diarrhea in Democratic Republic of Congo (DRC), Phytomedicine 7(2):167- 172.

Plotkin, M. J. (1991). Traditional Knowledge of Medicinal Plants the search for new jungle medicine. Cambridge University Press, Cambridge UK. 245-246.

Rates, S. M. K.(2001). Review: Plants as a source of drugs. Toxicon science directs, 39, 603-613.

Silva, G.L., I. Lee and K.A. Douglas, 1998. Special problems with extraction of plants In: Cannel, J.P.R. (ed.). Natural Products Isolation. Humana press publishers, New Jersey (USA). Pp 356-358. 
Sofowora, A. (1986). Retrospect and Prospects. In: The state of medical plants Research in Nigeria.University of Ife press, Ile - Ife Nigeria $1-10$.

Solecki, R. (1977). A Neanderthal flower burial in Northern Iraq. Science, 19, 880-881.

Trease and Evans, (2002), "Carbohydrates in Pharmacognosy", 5 $5^{\mathrm{TH}}$ edition, Ed. W.C. Evans, Harcourt Publisher Limted, London, Pp. 193

World Health Organization (WHO),(2003a). The promotion and Development of traditional Medicine, Technical Report Series, 622
Yesmin, M.N., Uddin, N.S., Sanzida, M., and Muhammad A. A. (2008). Antioxidant and Antibacterial Activities of Calotropis procera. American-Eurasian Journal of Agricultural and Environmental Science. 4 (5): 550-553

\section{APPENDICES}

From table 1 below, it could be seen that F-value was found to be significant at $1 \%$ probability. This implies that the plant extracts selected differed in their effect on Mycobacterium tuberculosis and the research therefore accepted the alternative hypothesis and rejects the null hypothesis that says the plant extracts (treatment) have the same effect in the treatment of Mycobacterium

tuberculosis.

Table 4: Analysis of Variance (ANOVA)

\begin{tabular}{llllll}
\hline Zone of Inhibition & Sum of Squares & Df & Mean Square & F & Sig. \\
\hline Between Groups & 283.734 & 4 & 70.933 & 4.659 & 0.008 \\
Within Groups & 304.492 & 20 & 15.225 & & \\
Total & 588.226 & 24 & & \\
\hline
\end{tabular}

** - Significant at 1\%

From the results in the table 2 it could be seen that the F-value which measure the level of dispersion or variation between or among the concentration levels was found to be significant at $1 \%$ probability and the research therefore has to accept the alternative hypothesis that says at least one of the concentration is having more significant effect in the treatment of Mycobacterium tuberculosis than others. The results show that $10000 \mu \mathrm{g} / \mathrm{ml}$ having a highest diameter of $16.98 \mathrm{~mm}$ will have more significant effect than the other concentration.

Table 2:Anova of Calotropis procera Concentration Levels on inhibition of Mycobacterium tuberculosis growth.

\begin{tabular}{llllll}
\hline Diameter $(\mathrm{mm})$ & Sum of Squares & Df & Mean Square & F & Sig. \\
\hline Between Groups & 2517.416 & 3 & 839.139 & 23.369 & $0.00^{* *}$ \\
Within Groups & 3447.211 & 96 & 35.908 & & \\
Total & 5964.628 & 99 & & & \\
\hline
\end{tabular}

Least significant difference was found to be 14.13 and from the table 8 below of the mean value of Calotropis procera Concentration Levels on inhibition of Mycobacterium tuberculosis growth showed that all the calculated means were lower than the LSD value which indicated that there was no significance difference between concentration levels hence the null hypothesis was rejected.

Table 8: Least significant difference (LSD) table of Calotropis procera Concentration Levels on inhibition of Mycobacterium tuberculosis growth.

\begin{tabular}{lll}
\hline Difference between Mean & Greater than $(>)$ or Less than $(<)$ LSD & Null hypothesis
\end{tabular}

\begin{tabular}{lccc}
\multicolumn{1}{c}{ Difference between Mean } & Greater than $(>)$ or Less than $(<)$ LSD & Null hypothesis & \\
\hline$\overline{\mathrm{X}}_{1}-\overline{\mathrm{X}}_{2}$ & $7.06-8.92$ & 1.86 & $\mathrm{H}_{\mathrm{o}}$ Rejected \\
$\overline{\mathrm{X}}_{1}-\overline{\mathrm{X}}_{3}$ & $7.06-11.96$ & 4.90 & $\mathrm{H}_{\mathrm{o}}$ Rejected \\
$\overline{\mathrm{X}}_{1}-\overline{\mathrm{X}}_{4}$ & $7.06-11.96$ & 4.90 & $\mathrm{H}_{\mathrm{o}}$ Rejected \\
$\overline{\mathrm{X}}_{1}-\overline{\mathrm{X}}_{5}$ & $7.06-16.98$ & 9.92 & $\mathrm{H}_{\mathrm{o}}$ Rejected \\
$\overline{\mathrm{X}}_{2}-\overline{\mathrm{X}}_{3}$ & $8.92-11.96$ & 3.04 & $\mathrm{H}_{\mathrm{o}}$ Rejected \\
$\overline{\mathrm{X}}_{2}-\overline{\mathrm{X}}_{4}$ & $8.92-11.96$ & 3.04 & $\mathrm{H}_{\mathrm{o}}$ Rejected \\
$\overline{\mathrm{X}}_{2}-\overline{\mathrm{X}}_{5}$ & $8.92-16.98$ & 8.06 & $\mathrm{H}_{\mathrm{o}}$ Rejected \\
$\overline{\mathrm{X}}_{3}-\overline{\mathrm{X}}_{4}$ & $11.96-11.96$ & 0.00 & $\mathrm{H}_{\mathrm{o}}$ Rejected \\
$\overline{\mathrm{X}}_{3}-\overline{\mathrm{X}}_{5}$ & $11.96-16.98$ & 5.02 & $\mathrm{H}_{\mathrm{o}}$ Rejected \\
$\overline{\mathrm{X}}_{4}-\overline{\mathrm{X}}_{5}$ & $11.96-16.98$ & 5.02 & $\mathrm{H}_{\mathrm{o}}$ Rejected \\
\hline
\end{tabular}

Key: $\bar{X}\left(\right.$ Mean) $\mathrm{H}_{\mathrm{o}}($ Null hypothesis)

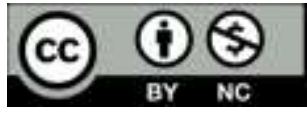

(C)2020 This is an Open Access article distributed under the terms of the Creative Commons Attribution 4.0 International license viewed via https://creativecommons.org/licenses/by/4.0/ which permits unrestricted use, distribution, and reproduction in any medium, provided the original work is cited appropriately. 